\title{
East-West Couples: Distribution, Characteristics and Stability
}

\section{Daniel Lois}

\begin{abstract}
SOEP data were used to examine relationships consisting of one partner socialised in West Germany and one in East Germany and who presently reside in the "old" (former West German) or "new" (newly formed East German) federal states. The estimated share of east-west couples among all marriages or cohabiting couples rises continuously within the observed period reaching approximately two and eleven percent respectively by 2009. The specific characteristics of east-west couples are that their employment-related division of labour is relatively egalitarian, above-average the partners are of different confessions and practice different religions, at least one of the partners is frequently divorced and there is also a strong tendency towards unmarried cohabitation. Besides the place of socialisation, the present place of residence has an independent impact on the economic situation, division of labour and marriage propensity. Analyses of relationship stability reveal that east-west couples exhibit a relatively high risk of separation. This is partly due to religious differences between the partners, but primarily to the low marriage propensity and the overrepresentation of divorced persons within this type of relationship.
\end{abstract}

Keywords: East-west differences · Internal migration · Relationship stability · Homogamy

\section{Introduction}

Immediately following reunification more than two decades ago, considerable flows of inner-German migration commenced. According to Fuchs-Schündeln and Schündeln (2009: 32-35), between 1991 and 2006 about two and a half million people, including returnees and multiple movers, migrated from the "new" (newly formed East German) to the "old" (former West German) federal states and about one million from the old to the new states. Within the population of internal migrants, married individuals are clearly under-represented (Fuchs-Schündeln/Schündeln 2009). We therefore expect that numerous east-west couples have formed in the mean- 
time, for example consisting of a woman socialised in former East Germany and a man who grew up in former West Germany. The phenomenon of "east-west love" appears to have a certain appeal, as we can see merely from a few media-covered occasions. For example, on 9 January 2009 over 100 east-west couples congregated in Berlin-Mitte to speak with Wolfgang Tiefensee, the then Federal government appointee for former East Germany, about the status of reunification (Berliner Kurier, 10.01.2009) and in February 2013 the German rock musician Udo Lindenberg sought ten east-west twosomes for his musical "Hinterm Horizont" (beyond the horizon; Hamburger Abendblatt, 19.02.13).

Previous research is not clear about the extent to which the east-west dimension is relevant for partner selection processes. A study by Rös/er (2010) shows that there are some stereotypes about typical western and eastern German traits. A survey of approximately three hundred Berlin students about their partner selection preferences demonstrates that empathy, eroticism and sexual openness, large circles of acquaintances and sociableness as well as a good family relationship are perceived as typically eastern German. Good manners, a high level of education, vocational success and economic independence are, by contrast, considered typically western German traits. It also became apparent that eastern and western German respondents each feel more connected with their own peers with regard to political and cultural issues. This indicates identification with their own ingroup with regard to the east-west categorisation.

In her book on "inner-German relationships," however, the journalist Simone Schmollack (2005) makes a rather optimistic assessment with regard to the "compatibility" of western and eastern Germans in intimate relationships. Based on qualitative interviews, she reports that conflicts do occur in these relationships that frequently centre on politics and in particular the recent German past and aspects such as reunification, unemployment and privatisation. Differing opinions about these issues are, however, less due to any "Ostalgie" or "Westalgie" (nostalgia for the East or West German past) than to the need to retain their own biographical identity within the relationship. She also diagnoses a weakening of east-west divergencies over time, stating, "east-west couples who met before the mid-1990s felt the cultural, emancipatory and economic differences more strongly than couples who met only a few years ago" (Schmollack 2005: 10, translated by CPoS). The conclusion in the book's blurb is therefore, "Nowhere is German reunification more evident than in the realm of love" (translated by CPoS).

Against the background of these contradictory findings, the objective of this article is to use the examples of east-west couples to examine the conflict between enduring socialisation experiences and adaptions to the socio-spatial context and new interaction partners. East-west couples are a special group inasmuch as entering into a relationship with people from the "receiving context" is considered an advanced stage of assimilation in migration research (Gordon 1964; Alba/Nee 2003). Consequently it is possible that differences between the partners are levelled in the course of partner selection and adaption processes. There is, however, also a possibility that norms and ideologies acquired during socialisation remain stable even in the context of internal migration and entering a new relationship. In this case differ- 
ences within east-west relationships could contribute to an increased instability of this form of relationship. This would be the equivalent of a sustained segmentation of social groups along the east-west dimension.

The study is structured as follows: In Section 2, we first discuss from a theoretical perspective what specific characteristics east-west couples exhibit. To do so, we employ a theoretical framework that differentiates between three determining factors: socialisation in former East Germany or former West Germany, adaptation of internal migrants to the present social environment and new interaction partners as well as the selectivity of geographically mobile people (Kulu/Milewski 2007; Milewski 2009). In Section 3, we then integrate the characteristics of the east-west couples into the model used to explain marital stability by Lewis and Spanier (1979). Following methodological remarks in the fourth section, in the empirical part (Section 5) we first use data from the German Socio-Economic Pane/ Study (SOEP) to explain how widespread east-west relationships are. ${ }^{1}$ The special status of Berlin must be taken into particular consideration since here the opportunities for east-west couples are especially favourable. Further analyses deal with the specific characteristics and the stability of these relationships. Finally, in Section 6 we summarise and discuss the results.

\section{Characteristics of east-west relationships in the context of socialisation, adaptation and selection effects}

The study of specific characteristics of east-west couples is based on a theoretical framework which differentiates between three hypotheses: the socialisation, adaptation and selection hypotheses (Kulu/Milewski 2007; Milewski 2009). According to the socialisation hypothesis, it is assumed that individual characteristics such as career orientation or religiousness determined by socialisation in former East Germany and former West Germany remain unchanged even if the individual is exposed to changed social contexts in the course of internal migration. Schneider et al. (1995) thus presume - using the key phrase "diverging modernisation" - that the different structural and cultural influences in former West Germany and former East Germany will not rapidly dissipate following reunification since the thoughts and actions of older birth cohorts, especially those born before 1970, were lastingly shaped by this.

The adaptation hypothesis is the opposite to the socialisation hypothesis, postulating that on the basis of acculturation and assimilation processes (Gordon 1964; Alba/Nee 2003), geographically mobile people adapt to the respective current context of life. At first, structural aspects of the socio-spatial context must be taken

1 Figures on the distribution of this type of relationship are presently lacking because in its statistics on marriages, the Federal Statistical Office only considers the present place of residence, but not the place in which individuals grew up before 1989. (Communication from the Federal Statistical Office dated 20 Nov. 2012 on inquiry) 
into consideration, such as employment possibilities or the availability of childcare facilities. The establishment of an east-west relationship also indicates a form of social assimilation, which is considered an advanced stage of assimilation in research on international migrants. Examples include the third stage of assimilation (marital assimilation) in Gordon (1964) or the process of boundary blurring in Alba and Nee (2003).

Finally, selection hypothesis is based on the assumption that individual characteristics of internal migrants deviate from the average non-mobile population (Ku/u/ Milewski 2007; Milewski 2009).

In the following sections, we will discuss the extent to which east-west couples with their place of residence in eastern or western Germany differ from couples with uniform West or East German socialisation in the light of socialisation, adaption and selection effects. The dimensions examined are the economic situation (Section 2.1), the couple's division of labour (Section 2.2), religiousness (Section 2.3) and familial living arrangements (Section 2.4). This quite heterogeneous selection is oriented primarily to the specific long-term consequences of the former division of Germany that have been highlighted by research (Schneider et al. 2012).

\subsection{The economic situation of east-west couples}

The current place of residence should be of primary importance with regard to a couple's economic situation, which can be expressed through material wealth (equivalent household income), impacts of unemployment and subjective assessments such as general life satisfaction. Because of poorer income and employment opportunities, greater impacts of economic shortcomings and unemployment are anticipated for east-west couples living in eastern Germany than for east-west couples living in western Germany. In the decades following reunification, however, there has been an economic east-west convergence, which can, according to current research, be divided into different phases (Göbel et al. 2010). In the first half of the 1990s, distinct progress was made with regard to convergence of equivalent household incomes and general life satisfaction, which slowed, however, between 1995 and 2000. Following the turn of the millennium, a renewed rise in income gaps and stagnation in satisfaction differences has been observed. The eastern population continues to be overrepresented in the low wage range, more affected by unemployment, has a higher percentage of long-term episodic poverty in addition to over-proportionally frequent losses of income over the course of the economic crises after the year 2000 (Göbel et al. 2010: 469). Accordingly, the socio-spatial east-west context should still continue to be linked to differences in the economic situations of couples today.

Regardless of the present place of residence, one could hypothesize that differing chances of prosperity among couples could also be caused by the place of socialisation. Intergenerational transfers are a good example for this assumption. A long-term consequence of former East Germany's planned economy is that, due to lesser asset values and residential property rates in eastern Germany, people 
socialised there are not only less likely to inherit property, but also lesser amounts when they do receive inheritances (Szydlik/Schupp 2004).

The selective characteristics of internal migrants, however, do not speak for any general economic disadvantage of couples with partners socialised in East Germany, since primarily young eastern people with above-average qualifications exhibit great willingness to migrate to the west (Windzio 2007; Fuchs-Schündeln/Schündeln 2009). To what extent east-west couples differ from couples with the same socialisation within the same socio-spatial context, for example east-west couples in western Germany from west-west couples in western Germany, is thus an empirical question.

\subsection{Couples' division of labour in east-west relationships}

According to the socialisation hypothesis, women socialised in East Germany would on average exhibit greater career orientation than women who grew up in former West Germany. The diverging social and family policies of the two regions are primarily responsible for this (Trappe 1995). The West German state long promoted the male breadwinner model, while East Germany early created the legal and institutional conditions, for instance with regard to childcare places, for women to return to the workplace soon after childbirth, enabling full-time employment for both sexes. If these socialisation experiences are long lasting, we anticipate that east-west couples with women socialised in East Germany would have a more egalitarian division of labour than west-west couples or east-west couples with women socialised in West Germany. With regard to selection effects it is also known that female east-to-west migrants are mostly well educated and correspondingly career oriented (Fuchs-Schündeln/Schündeln 2009).

Additionally, adaptation to the social context has probably gained significance. Against the background of the better availability of childcare facilities in eastern Germany (Hank et al. 2004) we can expect that couples living in eastern Germany, regardless of their socialisation experiences, have a more egalitarian division of labour than couples in western Germany. Acculturation processes are also possible, for example expressed in a drop in career orientation among women socialised in East Germany on their move to western Germany and adaptation to a partner who grew up in former West Germany. A study by Kalmijn (2005) with data from the Netherlands confirms that gender role orientations can adapt in relationships. Accordingly, over time men and women become more egalitarian (or more traditional), the more egalitarian (more traditional) their partner originally is. The extent of adaptation is, however, strongly dependent on the existence of children in the family and the employment constellation. Since no equivalent studies have been conducted on east-west couples, we must empirically examine whether diverging gender role orientations are levelled in these relationships as a result of adaptation processes. 


\subsection{Religiousness in east-west relationships}

The different significance of religion and church are among the most pronounced socio-cultural east-west differences. Western Germany has always been influenced by the southern German Catholic cultural tradition, while in eastern Germany the liberal or rather secular trends of the largely Protestant northeast traditionally dominate (Picke/ 2003). These long-term differences in the religious culture were even intensified by experiences with opposing political systems (Storch 2003). As a consequence of this, religiousness is far stronger in western Germany today than in the east. Based on the adult population living in private households, the estimated percentage of church members in western Germany in 2009 was over 80 percent and in eastern Germany even under 30 percent (Lois 2011). Consequently, according to the socialisation hypothesis, we would expect that east-west couples especially differ in their religiousness. This could be manifested in that only the partner who was socialised in West Germany is still member of a church and religiously active.

Regardless of socialisation experiences it is, however, possible that relationships only form between people of the same religion. But in the case of ecclesial religiousness, Klein and Wunder (1996) showed that confessional homogamy is largely not an expression of partner selection preferences, but instead a result of relative group sizes and corresponding opportunity structures. Accordingly, a religiously unaffiliated person socialised in East Germany, for example, who moves to western Germany, would have a greater chance, solely on the basis of the opportunity structures, to meet persons with confessions. According to the adaptation hypothesis, however, there is a possibility that differences between the partners' religiousness would be overcome over time through alignment. This assumption is, however, only partly supported by previous research. Lois (2013: 184-209) uses the example of church attendance to show that although there is a tendency in relationships to adapt to the partner over time, this tendency is far weaker than among comparable variables such as leisure activities. Therefore, the influences of socialisation should have relatively great significance.

Finally, there are also initial results concerning the extent to which east-west migrants are selective with regard to religiousness. Lois (2013: 173) shows that internal migrants between eastern and western Germany, regardless of the direction of their mobility, are significantly more often non-denominational and also less frequently attend church than non-mobile people (Vatterrott 2011 reaches similar results). Hence, while the socialisation as well as the adaptation hypothesis lead us to assume that especially the religious influences of partners in east-west relationships differ, this tendency would be weakened by the described selection mechanism. Therefore, the religious similarity in east-west couples is also a question of empirical interest. 


\subsection{The choice of familial living arrangements in east-west relationships}

The previously discussed east-west differences in economic situation, division of labour and religiousness should also contribute to the fact that familial living arrangements chosen in east-west relationships deviate from the average (of the German population). From the socialisation perspective, there are arguments for a stronger tendency towards unmarried cohabitation among partners socialised in East Germany. From a historical perspective, a strong distribution of children born out of wedlock can be traced primarily in eastern Germany back to the $19^{\text {th }}$ century. This was even intensified in the former state of East Germany through the introduction of the so called "baby year" which privileged single mothers (Schneider et al. 2012). In spite of the alignment of social laws, the east-west discrepancy with regard to children born out of wedlock has even become greater after reunification. In 2010 the share of children born out of wedlock among all firstborn children was 74 percent in eastern Germany (without Berlin), but only 37 percent in western Germany (Pötzsch 2012).

Additionally, according to the selection hypothesis, we must consider that people with at least one previous divorce in their life course are over-represented in the group of east-to-west internal migrants, primarily in the first wave of migration between 1990 and 1995 (Fuchs-Schündeln/Schündeln 2009). This selection effect should also contribute to a lower marriage propensity in east-west couples, since the probability of entering into a second or third marriage is lower than a first marriage (Lankuttis/Blossfeld 2003).

Arránz Becker and Lois (2010), however, find indications of adaption processes since originally single women with east-to-west mobility adapt to the marriage pattern of western German women although they maintain the socio-cultural influences of their eastern German origin, including a low religiousness and a relatively distinct career orientation. Adaption to a western German partner who, due to his socialisation experiences, would contribute an increased "marriage orientation" to the relationship may be responsible for this phenomenon. Although we can find more arguments that speak for a strong tendency towards unmarried cohabitation in east-west couples, this, again, is a question that would have to be answered empirically.

We also observe lasting east-west differences with regard to fertility behaviour following reunification. There was an apparent adaptation among the eastern German population to the new structural circumstances following 1990. The age at starting a family, which was far lower in East Germany than in former West Germany, rose rapidly after 1989, leading to a short-term drop in birth rates (Zapf/Mau 1993). However, in the years following reunification, eastern women exhibit a somewhat lower average age at the birth of their first child (27.4 years) than western women (29.2 years) (Pötzsch 2012); in addition lifelong childlessness is more widespread in western Germany than in the east (Statistisches Bundesamt 2009).

Therefore, with regard to starting families, we can assume that people socialised in East Germany have a lesser tendency to remain childless than people who grew 
up in former West Germany. Also people socialised in East Germany who migrate to western Germany appear to not adapt to the western German pattern of having their first child relatively late in the life course (Vatterrott 2011).

Furthermore, the specific characteristics of (female) east-to-west migrants, for instance their high level of education (Fuchs-Schündeln/Schündeln 2009; Windzio 2007), would lead us to expect a selection effect leading to an increased occurrence of childlessness in this group. The same conclusion can be drawn when taking the influence of the respective West German socialised partner into consideration whose socialisation experiences would, in turn, amount to the model of starting a family relatively late in the life course. For east-west couples living in western Germany, moreover, we must take into account the infrastructural effect of lower availability of childcare facilities, in particular for children under the age of three (Hank et al. 2004).

Against the background of this complex melange, it also needs to be empirically examined, to which extent east-west relationships differ with regard to starting families from the group of couples with the same socialisation backgrounds.

\section{$3 \quad$ Hypotheses on the stability of east-west relationships}

In the previous section, we assumed that east-west couples probably differ with regard to a number of characteristics from couples with uniform socialisation contexts. These assumed differences need not necessarily influence the satisfaction and the stability of an intimate relationship, since they may not be relevant, for example, in everyday couple communications and interactions. Not until there is evidence that east-west couples are instable to a significant degree due to their characteristics is a conclusion justified that there is still segmentation of social groups in reunified Germany along the east-west dimension.

Against this background, we will now formulate hypotheses on the risk of separation in east-west couples. As a theoretical basis for this we use a multidimensional and integrative model of marriage stability developed by Lewis and Spanier (1979) that incorporates social, individual and dyadic characteristics. ${ }^{2}$ Accordingly, subjective marital instability is the precondition of an actual divorce and is itself dependent on the quality of a marriage. The quality of a marriage is influenced by social and individual resources that are already determined at the beginning of the marriage, by the rewards of spousal interaction and by satisfaction with the present lifestyle.

Transferred to our question, east-west socialisation experiences lead to specific individual and social resources. We can render the somewhat imprecise definition of "resources" in Lewis and Spanier's model (1979) more precisely by making use of family economics (Becker 1981) thus differentiating between complementary and substitutable resources. The satisfaction and stability of the intimate relationship

2 Arránz Becker (2008: 29-37, 305-320) offers a detailed discussion and suggestions on further developing the model. 
increase when the partners are more similar in complementary characteristics such as religiousness. By contrast, specialisation and division of labour and thus partner dissimilarity can also be efficient in so called substitutable characteristics such as labour participation. The influences of the current socio-spatial context, for example the different income and employment opportunities in western and eastern Germany, directly influence the current satisfaction of the couple with their lifestyle.

In the model by Lewis and Spanier (1979), it also depends on external pressure that may exist to preserve the marriage and on available alternatives to the marriage whether a married couple actually divorces due to the low quality of a marriage and high subjective separation propensity. Here, there are also links to our questions since east-west couples should be over-represented in large urban contexts - primarily in Berlin - because more alternative partners are available (Schneider et al. 2012). We will return to this aspect in Section 5.1. In the following, we first describe the conclusions that can be drawn for the stability of east-west couples when taking differences in the economic situation, the division of labour, religiousness and familial living arrangements into account.

In Section 2.1, we described the hypothesis that couples currently living in eastern Germany and quite possibly couples in which at least one partner grew up in former East Germany are affected to a greater extent by economic difficulties. We can conclude from this that these couples are less stable (deprivation hypothesis), since economic deprivation as well as unemployment are destabilising relationships (see overview: Arránz Becker 2008: 32-35). This is primarily due to negative changes in couple interaction. When couples feel economically deprived there is an increased probability of dysfunctional perceptions and behaviours such as anxiety, depression and demoralisation. In addition, the couple's mutual support lessens and there are increased animosities and conflicts (Conger et al. 1990; Conger et al. 1999).

In addition to the amount of economic resources, there is the question of how the division of labour contributes to their production and the consequences on the relationship stability. Lewis and Spanier (1979) categorise this aspect along with the couple's economic situation under the label of "satisfaction with lifestyle." In current research, women's employment is considered the primary factor that increases the risk of separation among marriages, but not among cohabiting couples (Lois 2008). As Böttcher (2006) summarised, this is attributed to a lesser "marriage asset" as a result of the lack of efficiency through the division of labour, the woman's dual burden of housework and employment, a greater availability of alternative partners in the employment environment of the woman and the destabilising autonomy effect of the woman's income. Numerous studies provide evidence of the negative connection of female employment and marriage stability (see overview: Wagner/ Weiß 2003). We therefore assume that east-west marriages with wives socialised in East Germany as well as east-east marriages due to their more egalitarian division of labour are more instable than west-west marriages or east-west marriages with husbands socialised in East Germany (division of labour hypothesis).

Religiousness is a classic example of a complementary variable, which Lewis and Spanier (1979) count among the factors determined even before marriage. Theoreti- 
cally, we would expect that religious similarity of partners promotes positive couple interactions and decreases the probability of conflicts (see overview: Arránz Becker 2008: 62-71). Previous studies confirm these assumptions (e.g. Call/Heaton 1997; Wagner/Weiß 2003). As a result, this leads to the expectation that east-west couples are more instable than couples socialised in the same place since the religious influences of the partners more frequently differ (religious homogamy hypothesis).

Lewis and Spanier's theoretical model (1979) was moreover developed at a time when cohabiting couples were less widespread. However, Qian and Lichter (2007) point out that the increase in cohabiting couples can intensify the social distance between social groups in the context of interethnic relationships since this living arrangement is generally less stable than marriage, is linked to a lesser overlapping of spousal social networks and also is less often accompanied by the birth of children, which are considered relationship-specific investments in family economics. More frequent cohabitation and childlessness should, therefore, contribute to increased instability in east-west couples (cohabitation hypothesis, childlessness hypothesis).

Furthermore, as discussed in Section 2.4, the selectivity of east-west internal migrants must be taken into consideration, as they are more frequently divorced. Second marriages exhibit an increased risk of separation (Wagner/Weiß 2003). This is primarily attributed to the selective attributes of divorced people, such as the lack of interactive skills (Arránz Becker 2008: 59-60). From this we derive the second marriage hypothesis, which also leads us to anticipate increased instability in eastwest relationships.

\section{$4 \quad$ Data and methods}

\subsection{Data basis}

This study uses data from the German Socio-Economic Panel Study (SOEP, Wagner et al. 2007). The benefit of this data set is the availability of dyadic longitudinal data over an observation period of two decades (in this case 1990-2009). The sample is composed of 16,396 married and cohabiting couples (unmarried partners living together in one household), which could be observed in the SOEP surveys A-H since 1990. 87.2 percent of the observation episodes derive from marriages. Couples living in separate households cannot be included since there is no information about the respective partners in these cases.

Table 1 shows an overview of the numbers of cases broken down by couple types. The sample comprises 974 east-west couples. ${ }^{3}$ The number of east-west couples available here is far higher than in other data sets, such as the German Family Panel (pairfam), making the SOEP the best suitable data source for our study. However, with only 24 couples the type "eastern man-western woman" is too small

3 In 15.2 percent of the cases, the couple type is imputed due to missing information on the place of residence before 1989 (see Table A1). 
Tab. 1: Overview of numbers of cases and percentage of east-west couples

\begin{tabular}{|c|c|c|}
\hline & \multicolumn{2}{|c|}{ Current place of residence } \\
\hline & $\begin{array}{c}\text { Western Germany } \\
\text { (including West Berlin) }\end{array}$ & $\begin{array}{c}\text { Eastern Germany } \\
\text { (including East Berlin) }\end{array}$ \\
\hline Same place of residence before 1989 & $\begin{array}{l}\text { West-west couples } \\
\quad(\mathrm{n}=11,214)\end{array}$ & $\begin{array}{l}\text { East-east couples } \\
\qquad(\mathrm{n}=4,208)\end{array}$ \\
\hline $\begin{array}{l}\text { Different place of residence } \\
\text { before } 1989\end{array}$ & $\begin{array}{c}\text { Eastern woman- } \\
\text { western man } \\
\text { ( } \mathrm{n}=563,52.7 \%) \\
\text { Eastern man-western } \\
\text { woman } \\
(\mathrm{n}=259,27.3 \%)\end{array}$ & $\begin{array}{c}\text { Eastern woman- } \\
\text { western man } \\
(\mathrm{n}=128,17.2 \%) \\
\text { Eastern man-western } \\
\text { woman } \\
(\mathrm{n}=24,2.8 \%)\end{array}$ \\
\hline
\end{tabular}

Percentages weighted with cross-sectional extrapolation factors GPHRF-ZPHRF

Source: SOEP (1990-2009, own calculations)

in eastern Germany and is therefore excluded from descriptive statistics (Tables 3 and 4).

Table 1 additionally shows the percentage of different types of east-west couples. For example, 52.7 percent of the east-west couples are the type "eastern woman-western man" with their place of residence in western Germany. These percentages, unlike the absolute figures, are based on weighted calculations.

It would also be possible to analyse couples with the same socialisation contexts and internal migration, e.g. east-east couples who move to western Germany, but this would go beyond the scope of this study. The same applies to ethnically heterogamous couples.

The data are processed in the long format so that one line of the data set each accounts to one couple and one survey time. The data set comprises 122,049 observations. The observation period ends in cases of panel mortality, right-censoring in 2009 or a separation of the partners. The same person can be represented in multiple relationships over time.

\subsection{Method}

The empirical analyses include two steps. First, various characteristics are compared between the different types of couples. It must be taken into consideration that the east-west couples with an average couple age of 40.2 years are about nine years younger than west-west couples (49.6 years) and east-east couples $(49.2$ years). A simple descriptive comparison would therefore be hardly informative, since, in addition to the socialisation effects focused on, it would also always re- 
flect age differences. For this reason, the characteristics of the different couples are compared controlling for age, cohort and period effects. ${ }^{4}$

The methods used to analyse the characteristics of different couple types are so-called random effects (RE) models (Allison 2009: 21), which, weighted according to the respective variance, consider both differences within as well as between couples. Since one of the dependent variables, the absolute difference in church attendance of the partners, exhibits a high percentage of the value 0 , in this case an RE Poisson model is calculated (Allison 2009: 49-69). A (binary or multinomial) logistic regression model with panel-robust standard errors is used for dichotomous variables.

The second step involves analysis of the relative separation risk in the different couple types. For this, a discrete time event history analysis is used, which is specifically suited for panel data (Singer/Willett 2003: 357-406). For technical reasons related to the number of cases, a joint logit model is estimated for married and cohabiting couples. Since the logit coefficients in hierarchical regression models can change even without intercorrelation of the independent variables (Mood 2010), average marginal effects (AME) are reported which are not affected by this problem.

\subsection{Measures}

All independent variables were included time-lagged by one year in the analyses of relationship stability. Missing values were imputed for all independent variables using the expectation-maximisation method (Allison 2001: 19). Irregularly measured variables were updated to the respective current wave. The percentage of missing values, along with the descriptive statistics, is shown in Table A1 in the appendix.

Couple types:

- Information about where the respective respondent grew up prior to 1989 (West Germany, East Germany) is taken from the meta file "PPFAD." Since the "socialisation period" is shorter in younger birth cohorts in former West Germany and former East Germany, 5 further-reaching analyses are conducted in which the east-west couples are divided up into two groups (year of birth of the woman up to or after 1970). The current place of residence (western and eastern Germany) is also available for each wave even when changing over time.

Socio-economic situation and division of labour:

- The "index on the economic situation" is based on three indicators, which are first z-standardised and then combined by averaging the respective indicators (Cronbach's alpha ranging between .76 and .82). One is the equivalent household income (according to the new OECD scale). Since the research

4 The control variables here include the linear and squared age (couple average value), dummy variables for the respective observation period (1990-1995, 1996-2000, 2001-2005, reference: 2006-2009) as well as the year of birth operationalised as the couple average value and the squared year of birth.

5 About three-fourths of the people in east-west couples were born before 1974. The youngest person within this type of relationship was born in 1986. 
on relationship stability shows that economic deprivation is more stressful when perceived subjectively than objectively (Conger et al. 1999), indicators are also included on satisfaction with lifestyle (10-point rating scale) and on concerns about individual economic situations (3-point rating scale). Higher index values correspond to a better economic situation.

- Additionally, unemployment of one or both partners (for at least one month per year) is recorded.

- To describe the employment-related division of labour in couple relationships, we first formed an employment index for each partner that allocates full and part-time months extrapolated for the year as follows: full-time months $+\left(0.5^{*}\right.$ part-time months). Then we formed an average value for this index per couple (1.) as well as an adjusted partner difference (man-woman) (2.) (Griffin et al. 1999).

- To attain an indirect measurement of gender role orientation independent of employment behaviour, we made use of the hours estimated that each partner spends on weekends with housework and family chores (laundry, cooking, cleaning, childcare) measured in every second wave. Here, as well, we formed an average value per couple and an adjusted difference term (man-woman).

Religiousness:

- To measure religiousness, we employed the indicators church attendance (surveyed 1990, 1992, 1994-1999, 2001, 2003, 2005, 2007-2009) and confession (measured 1990, 1997, 2003, 2007). The question about church attendance offers four alternative response items $(4=$ every week, $3=\mathrm{ev}$ ery month, 2 = less often, $1=$ never), which is converted into an average value of annually attended church service (never $=0$, less often $=5$, every month $=12$, every week $=52$ ). We again formed an average value per couple as well as an absolute difference for the partners. In the case of confession, we differentiated between three constellations in the analyses of relationship stability: (1.) both partners lack a confession, (2.) partners' confessions differ or only one partner has no confession (heterogamy) and (3.) the partners are of the same confession (homogamy).

Familial living arrangements:

- The SOEP files "biobirth," "biobirthm" and "biomarsy" are used to differentiate married or cohabiting couples (previously divorced and not, i.e. at least one partner is previously divorced) and whether both partners are childless. The analyses of relationship stability also incorporate counter variables on the number of 0 to 1-year-old, 2 to 4 -year-old and over 4-year-old children currently living in the respective household measured according to their relationship to the head of the household.

Durations in the discrete-time event history analysis:

- In the cases of marriages, the marriage duration is taken from the "biomarsy" file as the event indicator and operationalised as a linear and logarithmised term to model a sickle-shaped separation risk.

- The SOEP data is limited in that no information on the relationship duration is available that could be used as a suitable event indicator for cohabiting couples. Instead, we used the ages, which typically correlate highly with the relationship duration. 


\section{$5 \quad$ Empirical results}

\subsection{How has the share of east-west couples changed since 1990?}

The first step of the empirical analyses asks about the social relevance of the phenomenon of "east-west love". Figure 1 shows how the distribution of east-west couples has developed since 1990. The estimated results are based on weighted data (SOEP cross-sectional weights PHRF) used to adapt them to marginal distributions of official microcensus data (Göbel et al. 2008). It shows a distinctly positive trend. While practically no relationships were observed between East and West-German socialised people in 1990, their percentage among all married couples increased to 1.7 percent by 2009 and among cohabiting couples even to 11 percent.

The distinct differences between married and cohabiting couples have a number of possible causes. Generally, east-west couples only have had the opportunity to meet since 1990 and younger people are over-represented in the group of eastto-west internal migrants (Fuchs-Schünde/n/Schündeln 2009). Therefore, the large number of cohabiting couples is probably largely due to age and relationship dura-

Fig. 1: Development of the share of east-west couples among all cohabiting and married couples in the period 1990-2009

Percent

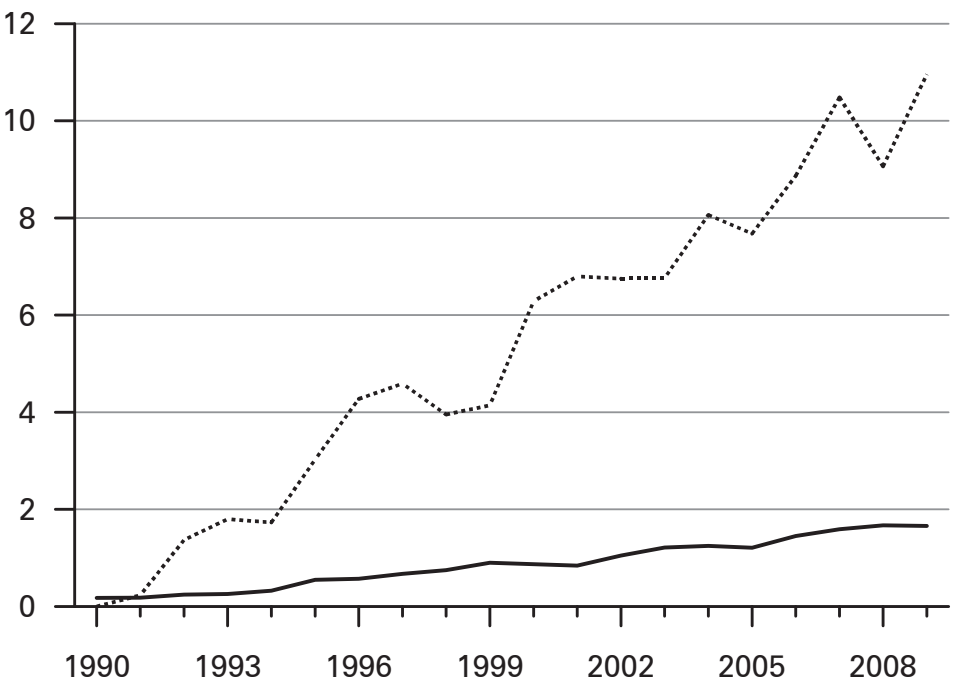

Share of east-west couples among all cohabiting couples

Share of east-west couples among all marriages

Weighting with cross-sectional extrapolation factors GPHRF-ZPHRF

Source: SOEP (1990-2009, own calculations) 
tion effects. In addition, in Section 2.4 we already assumed that east-west couples, regardless of their age, exhibit a lower marriage propensity compared to west-west couples. We will analyse whether this is true in Section 5.2.

In-depth analyses also reveal that 3.1 percent of Berlin marriages and 25.3 percent of Berlin cohabiting couples are east-west couples, which can be explained by the favourable opportunities of their meeting.

In summary, the internal migration flows between eastern and western Germany since the year 1990 have apparently contributed to an increased number of eastwest relationships. This result alone, however, does not explain whether relationships can be classified according to the east-west criterion and thus implying that this criterion is accompanied by specific socio-cultural and economic characteristics. The following section will explore this question.

\subsection{Comparing characteristics of east-west relationships}

Tables 2 and 3 compare various characteristics between couple types. In order to isolate influences of the place of socialisation and socio-spatial context as much as possible, multivariate models are calculated with a series of control variables (not shown).

Table 2 (model 1) analyses the index on the economic situation, which, along with the equivalent household income, includes satisfaction with the living standard and worries about the economic situation. The structurally better income and employment opportunities in western Germany can be seen in that the economic situation of couples living in eastern Germany (couple types "east-east" as well as "eastern woman-western man") is altogether considerably poorer than that of couples living in western Germany. The independent effect of the socio-spatial context is revealed in particular by the fact that couples of the type "eastern woman-western man" with a place of residence in eastern Germany are in economically less favourable positions than the same type of couple living in western Germany. Although the results thus clearly speak in favour of a socio-geographical adaptation mechanism, we must not completely neglect socialisation experiences. For example, the east-west couples of the type "eastern woman-western man" and "eastern manwestern woman" have a somewhat less advantageous economic situation than the reference category of west-west couples, with whom they share the socio-spatial context. One possible explanation for this finding is, for instance, that partners socialised in East Germany have disadvantages with regard to intergenerational transfers. In addition, causal effects may result from the internal migration as such, for example when the entry into employment and the career advancement of one partner is delayed due to migration.

The results concerning the unemployment of one or both partners (models 2-3 in Table 2) are similar to those in model 1, whereas the general significance of the socio-spatial context is somewhat more distinct.

In addition to available material resources, the question is how these are produced with regard to the couples' division of labour. The dependent variable in model 4 (Tab. 2) is an adjusted difference term that provides information about the 
Tab. 2: Economic situation, unemployment and division of labour in couple types, by place of socialisation and current place of residence (b coefficients with panel-robust $t$ or $z$ values in brackets)

\begin{tabular}{|c|c|c|c|c|}
\hline & \multicolumn{4}{|c|}{ Model } \\
\hline & 1 & 2 & 3 & 4 \\
\hline & $\begin{array}{l}\text { Index of economic } \\
\text { situation }\end{array}$ & $\begin{array}{l}\text { Both unem- } \\
\text { ployed } \\
\text { (ref.: neither) }\end{array}$ & $\begin{array}{l}\text { One unem- } \\
\text { ployed } \\
\text { (ref.: neither) }\end{array}$ & $\begin{array}{c}\text { Employment } \\
\text { index } \\
\text { (man-woman) }\end{array}$ \\
\hline & RE linear & Multinomia & logit model & RE linear \\
\hline \multicolumn{5}{|l|}{ Couple type } \\
\hline $\begin{array}{l}\text { West-west couple, western } \\
\text { Germany (reference) }\end{array}$ & - & - & - & - \\
\hline $\begin{array}{l}\text { East-east couple, } \\
\text { eastern Germany }\end{array}$ & $(-40.3)$ & $\begin{array}{l}.88^{* *} \\
(17.8)\end{array}$ & $\begin{array}{l}.69 * * \\
(21.4)\end{array}$ & $\begin{array}{l}-1.44^{* *} \\
(-19.4)\end{array}$ \\
\hline $\begin{array}{l}\text { East(w)-west(m) couple, } \\
\text { western Germany }\end{array}$ & $\begin{array}{l}-.07^{* *} \\
(-3.3)\end{array}$ & $\begin{array}{r}.09 \\
(0.7)\end{array}$ & $\begin{array}{l}.14^{+} \\
(1.7)^{+}\end{array}$ & $\begin{array}{l}-.32^{*} \\
(-2.0)\end{array}$ \\
\hline $\begin{array}{l}\text { East(m)-west(w) couple, } \\
\text { western Germany }\end{array}$ & $\begin{array}{l}-.07^{*} \\
(-2.1)\end{array}$ & $\begin{array}{r}-.32 \\
(-1.5)\end{array}$ & $\begin{array}{r}.09 \\
(0.7)\end{array}$ & $\begin{array}{l}-.60^{*} \\
(-2.4)\end{array}$ \\
\hline $\begin{array}{l}\text { East(w)-west(m) couple, } \\
\text { eastern Germany }\end{array}$ & $\begin{array}{l}-.23^{* *} \\
(-5.4)\end{array}$ & $\begin{array}{l}.68^{*} \\
(2.1)\end{array}$ & $\begin{array}{l}.92^{* *} \\
(5.5)\end{array}$ & $\begin{array}{l}-1.91^{* *} \\
(-5.5)\end{array}$ \\
\hline n (couples) & 16,372 & & 14,606 & \\
\hline n (observations) & 122,049 & & 101,824 & \\
\hline
\end{tabular}

$+\mathrm{p} \leq .10 ;{ }^{*} \mathrm{p} \leq .05 ;{ }^{*} \mathrm{p} \leq .01$

$\mathrm{RE}=$ Random Effects

Models 2-4: Both partners of working age

Control variables: Linear and squared age (average value per couple); period dummies; year of birth (average value per couple), year of birth squared; familial living arrangement (married vs. cohabiting couples); number of children living in household (0-1 years, 2-4 years, over 4 years; only model 4 )

Source: SOEP (1990-2009, own calculations)

couples' division of labour outside the home. It is the difference between the annual full and part-time months worked by the male partner and those of the female partner. Here, high values indicate a more traditional orientation of the couple (the man works longer hours than the woman). ${ }^{6}$ East-west couples living in western Germany are significantly more egalitarian in this respect than west-west couples, indicating an enduring effect of socialisation. Further analyses at the individual level reveal that in both cases women in east-west relationships - compared with westwest couples - are responsible for the greater labour participation. A selection ef-

6 Bottom and ceiling effects are controlled for by using the respective couple average values, which are included in the form of a linear and squared term. If, for example, neither partner is employed they cannot, trivially, differ in the extent of their labour participation (bottom effect). 
fect may, however, be an alternative explanation to socialisation influences, since female east-to-west migrants are predominantly highly educated.

Moreover, we again observe that east-west couples of the type "eastern womanwestern man" differ distinctly depending on the place of residence. The couples of this constellation living in eastern Germany practice a far more egalitarian division of labour. This is yet more evidence of an independent effect of the socio-spatial context, which could, in this case, be caused by the better availability of childcare facilities in eastern Germany.

To further isolate independent socialisation effects, we additionally analysed the domestic weekend division of labour, which should be less influenced by structural factors such as available childcare places and employment opportunities. The dependent variable is an adjusted difference term (man-woman) on the hours that each of the partners spend doing housework. The results (not shown) reveal hardly any significant differences between the couple types. Only east-east couples are significantly more egalitarian than west-west couples. These results tend to deny that there are east-west differences in gender role orientations which are independent from opportunity structures.

Table 3 covers the analyses of partner similarities regarding religiousness as well as familial living arrangements. The dependent variable in model 1 takes on the value 1 if the partners are members of the same denomination (confessional homogamy). If, however, the partners are of different confessions or if only one partner is non-denominational, the value is set at 0 . The results show that the confessions of partners in east-west relationships differ significantly more often than of west-west couples regardless of whether the east-west couple currently lives in eastern or western Germany. While the religious affiliation of the partners does not agree in 50.4 percent of cases of east-west couples living in western Germany in which the woman was socialised in East Germany, this is true for only 28.2 percent of the cases of west-west couples.

Also of interest in model 2 is the extent to which-controlled for confessional homogamy - differences in the partners' religious practices can be determined. The dependent variable is the absolute difference in church attendance of the partners. This difference is significantly more distinct within east-west couples than west-west couples. The current place of residence only plays a minor role here. Altogether, the results on religiousness clearly speak for the enduring significance of diverging socialisation experiences. The religious differences within east-west couples can apparently not be completely overcome by partner selection preferences or adaptation processes over time or be balanced out by selection effects. ${ }^{7}$

Model 3 furthermore examines whether the different couple types are cohabiting (coded with 0 ) or married (coded with 1). In model 4, the dependent variable reaches the value 1 if at least one partner is previously divorced.

7 In addition, differences in the level of religiousness between the different couple types must be taken into account. For example, the mean frequency of church attendance extrapolated to the year among east-west couples with women socialised in East Germany and living in western Germany is only 4.0 annual church visits, but 10.7 for west-west couples. 
Tab. 3: Religiousness and familial living arrangements in couple types by place of socialisation and current place of residence (b coefficients with panel-robust t or $z$ values in brackets)

\begin{tabular}{|c|c|c|c|c|}
\hline & \multicolumn{4}{|c|}{ Model } \\
\hline & \multirow{3}{*}{$\begin{array}{c}1 \\
\text { Confessional } \\
\text { homogamy } \\
\text { Logit }\end{array}$} & 2 & \multirow{2}{*}{$\begin{array}{c}3 \\
\text { Married (1) ver- } \\
\text { sus cohabiting } \\
\text { couples }(0)\end{array}$} & \multirow{3}{*}{$\begin{array}{c}4 \\
\text { Previously } \\
\text { divorced }\end{array}$} \\
\hline & & $\begin{array}{l}\text { Church attendance } \\
\text { (|man-woman|) }\end{array}$ & & \\
\hline & & RE Poisson & Los & \\
\hline \multicolumn{5}{|l|}{ Couple type } \\
\hline $\begin{array}{l}\text { West-west couple, western } \\
\text { Germany (reference) }\end{array}$ & - & - & - & - \\
\hline $\begin{array}{l}\text { East-east couple, } \\
\text { eastern Germany }\end{array}$ & $\begin{array}{l}-.75^{* *} \\
(-13.6)\end{array}$ & $\begin{array}{l}-.06^{* *} \\
(-3.6)\end{array}$ & $\begin{array}{l}-.33^{* *} \\
(-6.1)\end{array}$ & $\begin{array}{r}.04 \\
(0.8)\end{array}$ \\
\hline $\begin{array}{l}\text { East }(w) \text {-west }(m) \text { couple, } \\
\text { western Germany }\end{array}$ & $\begin{array}{l}-.88^{* *} \\
(-7.6)\end{array}$ & $\begin{array}{l}.07^{* *} \\
(3.0)\end{array}$ & $\begin{array}{l}-1.39^{* *} \\
(-10.6)\end{array}$ & $\begin{array}{l}1.45^{* *} \\
(11.5)\end{array}$ \\
\hline $\begin{array}{l}\text { East }(m) \text {-west }(w) \text { couple, } \\
\text { western Germany }\end{array}$ & $\begin{array}{l}-.46^{* *} \\
(-3.1)\end{array}$ & $\begin{array}{l}.09^{*} \\
(2.4)\end{array}$ & $\begin{array}{l}-1.30^{* *} \\
(-7.0)\end{array}$ & $\begin{array}{l}1.74^{* *} \\
(10.0)\end{array}$ \\
\hline $\begin{array}{l}\text { East }(w) \text {-west }(m) \text { couple, } \\
\text { eastern Germany }\end{array}$ & $\begin{array}{l}-.78^{* *} \\
(-3.9)\end{array}$ & $\begin{array}{l}.21^{* *} \\
(4.3)\end{array}$ & $\begin{array}{l}-2.38^{* *} \\
(-8.1)\end{array}$ & $\begin{array}{l}1.60^{* *} \\
(6.1)\end{array}$ \\
\hline n (couples) & 14,970 & & 16,372 & \\
\hline n (observations) & 97,121 & & 122,049 & \\
\hline
\end{tabular}

$+\mathrm{p} \leq .10 ;{ }^{*} \mathrm{p} \leq .05 ; * * \mathrm{p} \leq .01$

$\mathrm{RE}=$ Random Effects

Model 1 without homogamous religiously unaffiliated couples

Control variables: Linear and squared age (average value per couple); period dummies; year of birth (average value per couple), year of birth squared; familial living arrangement (marriage vs. cohabiting couples; only models 1 and 2), linear and squared average value for religiousness per couple and dummy for confessional homogamy (only model 2); number of children living in household (0-1 years, 2-4 years, over 4 years; only model 3)

Source: SOEP (1990-2009, own calculations)

The results shown in model 3 illustrate that east-west couples, even when controlled for age effects and children, tend to cohabit far more than west-west couples, who exhibit the overall greatest marriage orientation. The marriage propensity in east-west relationships, regardless of the current place of residence, is far lower than in east-east relationships. Since we controlled for age effects, this finding indicates delays in the institutionalisation process among east-west relationships (Kopp et al. 2010). One simple explanation that cannot be tested due to data restrictions is that east-west couples did not have the opportunity to meet until 1990 and therefore probably exhibit shorter relationship durations on average. The independent significance of the socio-spatial context is again expressed in the fact that couples of the type "eastern woman-western man" living in eastern and western Germany 
differ since the marriage propensity of couples residing in eastern Germany is comparatively lower.

Model 4 also reveals that one partner in east-west couples was more frequently previously divorced. Additional analyses show that, in agreement with the research (Fuchs-Schündeln/Schündeln 2009), this is primarily true of the migrant partner. According to further analyses, the selectivity of east-west couples with regard to previous divorces is also to some extent responsible for their low marriage propensity, which model 3 documents.

In analyses not shown here, we also pursued the question whether the level of childlessness among east-west couples differs significantly from west-west couples, controlled for the two living arrangements cohabitation and marriage. The results show that in this case no statistically significant differences can be ascertained, thus contradicting the childlessness hypothesis. Only east-east couples are, as expected, significantly less often childless than the reference group of west-west couples.

In order to test cohort-specific differences, we also compared the results portrayed in Tables 2 and 3 between two groups: couples in which the woman was born up to or after 1970. No significant differences were revealed for economic situation, division of labour inside and outside the home or religiousness. With regard to marriage propensity and previous divorces, however, cohort effects were verifiable since the marriage propensity among east-west couples of younger birth cohorts increases and the percentage of previously divorced people decreases. One explanation for these findings is that the selective characteristics of the east-west internal migrants changed over time. People socialised in East Germany who moved their place of residence to western Germany during the second major wave of migration between 1997/1998 and 2004/2005 are, compared with the first migration wave in the early 1990s, younger and less often previously divorced, factors that may have an inhibitive effect on remarriage (Fuchs-Schündeln/Schündeln 2009).

\subsection{How stable are east-west couples?}

Based on the analyses in the previous section, we can draw the preliminary conclusion that east-west couples, as expected, exhibit some "risk factors" that may contribute to increased instability. These include the differences in confessions and the distinct propensity towards unmarried cohabitation. Now, using the event history analyses as shown in Table 4, we test the extent to which the risk of separation differs between the different couple types and how these differences can be explained.

Based on model 1 we learn that the conditional probability of separation among east-west couples with their place of residence in western Germany is 1.2 percentage points and among east-west couples living in eastern Germany 1.5 percentage points higher than among the reference category of west-west couples. ${ }^{8}$ Both of

8 East-west couples in former West and East Germany are each allocated to one group for the sake of case numbers. 
Tab. 4: Discrete-time event history analysis of the risk of separation in couple types by current place of residence and place of socialisation (average marginal effects with $z$ values in brackets)

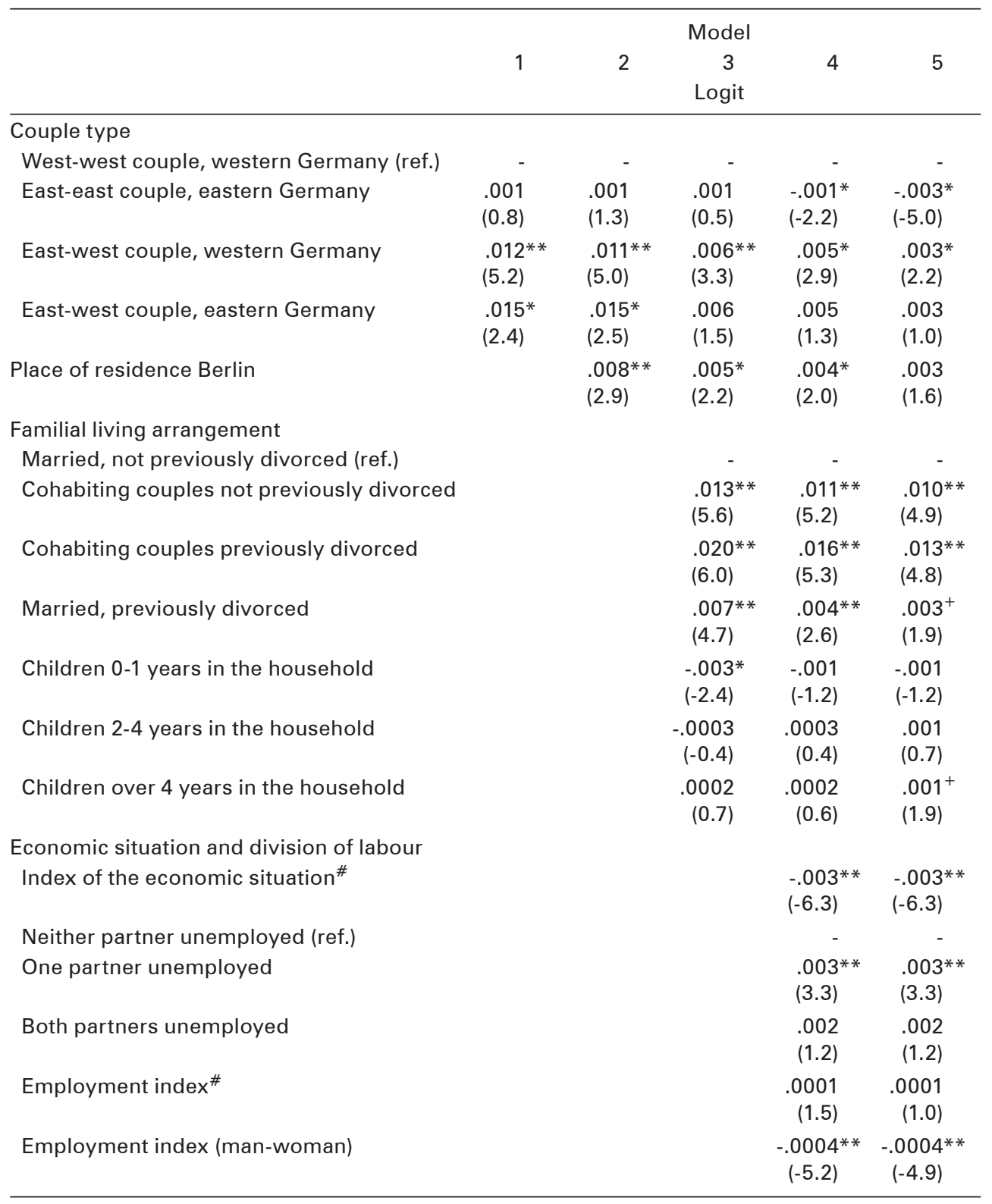


Tab. 4: Continuation

\begin{tabular}{|c|c|c|c|c|c|}
\hline & \multicolumn{5}{|c|}{ Model } \\
\hline & 1 & 2 & $\begin{array}{c}3 \\
\text { Logit }\end{array}$ & 4 & 5 \\
\hline $\begin{array}{l}\text { Employment index (man-woman) } \times \\
\text { Cohabiting couples not previously divorced }\end{array}$ & & & & $\begin{array}{r}.0001 \\
(0.5)\end{array}$ & $\begin{array}{r}.0001 \\
(0.4)\end{array}$ \\
\hline $\begin{array}{l}\text { Employment index (man-woman) } \times \\
\text { Cohabiting couples previously divorced }\end{array}$ & & & & $\begin{array}{c}.0003^{*} \\
(2.5)\end{array}$ & $\begin{array}{c}.0003^{*} \\
(2.4)\end{array}$ \\
\hline $\begin{array}{l}\text { Employment index (man-woman) } \times \\
\text { Married, previously divorced }\end{array}$ & & & & $\begin{array}{l}.0005^{* *} \\
(3.4)\end{array}$ & $\begin{array}{l}.0004^{* *} \\
(3.2)\end{array}$ \\
\hline \multicolumn{6}{|l|}{ Religiousness } \\
\hline Church attendance ${ }^{\#}$ & & & & & $\begin{array}{l}-.0003^{* *} \\
(-6.2)\end{array}$ \\
\hline Church attendance (|man-woman|) & & & & & $\begin{array}{l}.0001^{* *} \\
(2.8)\end{array}$ \\
\hline Confessional heterogamy (ref.) & & & & & - \\
\hline Both partners non-denominational & & & & & $\begin{array}{l}-.001 \\
(-0.8)\end{array}$ \\
\hline Confessional homogamy & & & & & $\begin{array}{l}-.004^{* *} \\
(-7.6)\end{array}$ \\
\hline \multicolumn{6}{|l|}{ Process times } \\
\hline $\mathrm{Age}^{\#}$ & $\begin{array}{l}-.001^{* *} \\
(-23.4)\end{array}$ & $\begin{array}{l}-.001^{* *} \\
(-23.8)\end{array}$ & $\begin{array}{l}-.0005^{* *} \\
(-11.5)\end{array}$ & $\begin{array}{l}-.0004^{* *} \\
(-10.3)\end{array}$ & $\begin{array}{l}-.0004^{* *} \\
(-10.3)\end{array}$ \\
\hline Marriage duration (+1) & & & $\begin{array}{l}-.001^{* *} \\
(-7.0)\end{array}$ & $\begin{array}{l}-.001^{* *} \\
(-7.5)\end{array}$ & $\begin{array}{l}-.001^{* *} \\
(-6.9)\end{array}$ \\
\hline Marriage duration (+1) logarithmised & & & $\begin{array}{l}.003^{* *} \\
(3.8)\end{array}$ & $\begin{array}{l}.003^{* *} \\
(4.3)\end{array}$ & $\begin{array}{l}.003^{* *} \\
(3.9)\end{array}$ \\
\hline Pseudo-r² (McFadden) & .076 & .078 & .102 & .109 & .116 \\
\hline n (couples) & & & 16,396 & & \\
\hline n (observations) & & & 122,049 & & \\
\hline $\begin{array}{l}n \text { (separation events, married/cohabiting } \\
\text { couples) }\end{array}$ & & 1,32 & $23(772$ / 551) & & \\
\hline
\end{tabular}

** $\mathrm{p} \leq .01 ; * \mathrm{p} \leq .05 ;+\mathrm{p} \leq .10$

\# $=$ Operationalised as average value per couple

Source: SOEP (1990-2009, own calculations)

these differences are highly significant and, since it is a matter of percentage points, also of considerable magnitude. Another example illustrates this more clearly: at about 5 percent, the probability of separation for an average couple age of 30 years among all east-west couples put together is twice as high than among the most stable group, the west-west couples (2.5 percent probability of separation at this age).

In order to explain these differences, we now gradually include variables into the regression model that can be allocated to different dimensions. Model 2 first takes account of a socio-spatial selection mechanism. In Section 4.1 we already noted 
that east-west couples are especially to be found in Berlin. In addition, model 2 shows that the risk of separation in urban contexts such as Berlin is higher, probably also due to greater availability of alternative partners (Arránz Becker 2008: 41-44). The coefficients for east-west couples, however, are only slightly lower when controlled for the Berlin dummy in model 2.

In model 3 we control for familial living arrangements by considering the children living in the household as well as by differentiating between cohabiting and married couples, each with and without one previously divorced partner. In line with current research, marital living arrangements reveal stabilising effects compared to cohabiting arrangements (Kopp et al. 2010). At the same time relationships in which at least one partner is previously divorced are less stable (Wagner/Weiß 2003). Moreover, we also confirmed the stabilising effect of small children (in the age range of 0-1 year). When controlled for familial living arrangements, the net differences between east-west couples and west-west couples decrease considerably and are no longer significant in the case of east-west couples living in eastern Germany. After further analyses, it becomes clear that this major effect reduction is primarily a consequence of the greater prevalence of cohabiting couples and remarriages among east-west couples. We consider this strong evidence for the second marriage hypothesis and the cohabitation hypothesis.

The fourth model includes indicators that illustrate both the couple's economic situation and their gender-specific division of labour. It confirms that couples with a more favourable economic situation are more stable $(b=-.003)$ and also that unemployment of one partner has a destabilising effect. With regard to the division of labour outside the home, the conditional main effect of the difference term "employment index man - employment index woman" (AME $=-.0004)$ shows that marriages with no previously divorced partner are stabilised by a traditional division of labour. As the significant interaction effects document, however, this context is transferable to neither married nor cohabiting couples in which at least one partner was previously divorced. The remaining multivariate difference between east-west couples in western Germany and west-west couples only marginally drop when comparing models 3 and 4 . Therefore, contradicting deprivation and division of labour hypothesis, the increased instability of east-west relationships can hardly be explained by the economic situation and division of labour.

Finally, model 5 considers religiousness. As expected, couples who on average attend church services relatively frequently are more stable (AME $=-.0003$; level effect). In addition, the risk of separation increases when the partners are not of the same confession or they practice their religion differently (AME $=-.004$ for confessional homogamy and $\mathrm{AME}=.0001$ for the absolute difference in church attendance). Differences in religiousness are not irrelevant for the stability of east-west couples: comparing models 4 and 5 , a drop in the effect is observed for east-west couples in western Germany (from .005 to .003). This finding at least tends to support the religious homogamy hypothesis. 


\section{Summary and discussion}

The initial key result of this study ascertained that relationships between a person socialised in West Germany and one in East Germany have become increasingly widespread in quantity. As a consequence of internal migration flows since reunification the estimated share of east-west couples among all married couples increased to 1.7 percent and among cohabiting couples to 11 percent in 2009. Moreover, this form of relationship is especially to be found in western Germany, in particular in Berlin.

Figures on the incidence of east-west couples do not, however, answer the question of why to differentiate intimate relationships according to the current place of residence in western and eastern Germany and according to the place of socialisation. Further analyses confirm, however, that the current socio-spatial context and the place of socialisation are accompanied by systematic differences with regard to their economic welfare as well as the partners' socio-cultural influences. Independent contextual influences are expressed primarily in that distinct socio-spatial differences are exhibited when controlling for the couple's socialisation experiences. For instance, east-west couples in which the woman was socialised in East Germany and the man in West Germany and who live in eastern Germany exhibit poorer economic situations, a more egalitarian division of labour and a lower marriage propensity than couples of the same type living in western Germany.

At the same time, we found indications that socialisation influences are not completely levelled even over the course of internal migration and social assimilation. This is confirmed, for example, by the fact that east-west couples living in western Germany are characterised by a less favourable economic situation and a more egalitarian division of labour outside the home than west-west couples living in the same socio-spatial context. The most striking example for the significance of socialisation is, in addition, the difference in religiousness within east-west couples. Here, the results reveal that both the religious affiliation as well as the frequency of church attendance especially differ among partners in east-west relationships.

Nonetheless, we note that alternative explanations for our findings related to the selectivity of internal migrants cannot be ruled out. For example, the relatively egalitarian division of labour among east-west couples might also be ascribed to the fact that female internal migrants are highly educated and thus exhibit a higher career orientation. It would be necessary to observe internal migrants before and after migration in an enhanced analysis design in order to completely differentiate selection and adaptation effects.

Another important result of this study is that the characteristics of east-west couples previously discussed have consequences for the stability of this type of relationship. East-west couples are significantly less stable than German couples of identical socialisation. The event history analyses illustrated that this increased instability is in part due to diverging confessional affiliations and religious practices. Consequently, in terms of religiousness, a cultural distance can be found between people socialised in West and East Germany, which contributes not only to increased instability of intimate relationships but also tends to solidify boundaries 
between social groups along the east-west dimension. Confession and church attendance are, however, merely indirect indicators of basic values and lifestyles. Therefore, further analyses should analyse how religious differences actually affect couple interaction.

However, with surprisingly clarity the primary cause for the increased risk of separation in east-west relationships is shown to lie in the sphere of familial living arrangements and relationship histories: east-west couples separate relatively often, primarily because they are often unmarried and at least one of the partners is frequently previously divorced. The low marriage propensity is potentially due to the shorter average relationship duration of east-west couples, who only had the opportunity to meet since reunification. The notably large number of previously divorced people in this population group can most probably be explained through a selection effect, since, according to current research findings, divorced people exhibit greater probability of migrating within Germany.

The question is whether these characteristics of east-west couples will disappear among younger cohorts. This would be the case should this group conform to the "average couple" in the general population. The opposite case is also not entirely implausible. In a certain way, east-west relationships are "ahead of their time," since some striking parallels can be observed between their specific characteristics - like egalitarian division of labour, unmarried cohabitation, confessional heterogamy - and various general trends. These include the rise in marriage age and the increase in cohabiting couples (Peuckert 2008: 32-47), the rise in female labour participation (Peuckert 2008: 229-283) and the increase in the number of interreligious marriages (Klein/Wunder 1996). For this reason, the extent to which the inner-German east-west comparison becomes increasingly obsolete on account of the general modernisation trend will remain a fascinating question, even in the context of intimate relationships.

\section{References}

Alba, Richard D.; Nee, Victor 2003: Remaking the American mainstream: Assimilation and contemporary immigration. Cambridge, MA: Havard University Press.

Allison, Paul D. 2001: Missing data. Quantitative applications in the social sciences 136. Thousand Oaks: Sage.

Allison, Paul D. 2009: Fixed effects regression models. Quantitative applications in the social sciences 160. Thousand Oaks: Sage.

Arránz Becker, Oliver 2008: Was hält Partnerschaften zusammen? Psychologische und soziologische Erklärungsansätze zum Erfolg von Paarbeziehungen. Wiesbaden: VS Verlag.

Arránz Becker, Oliver; Lois, Daniel 2010: Unterschiede im Heiratsverhalten westdeutscher, ostdeutscher und mobiler Frauen. Zur Bedeutung von Transformationsfolgen und soziokulturellen Orientierungen. In: Soziale Welt 61: 5-27 [doi: 10.5771/00386073-2010-1-5].

Becker, Gary S. 1981: A treatise on the family. Cambridge/London: Harvard University Press. 
Böttcher, Karin 2006: Scheidung in Ost- und Westdeutschland. Der Einfluss der Frauenerwerbstätigkeit auf die Ehestabilität. In: Kölner Zeitschrift für Soziologie und Sozialpsychologie 58,4: 592-616 [doi: 10.1007/s11577-006-0258-1].

Call, Vaughn R. A.; Heaton, Tim B. 1997: Religious influence on marital stability. In: Journal for the Scientific Study of Religion 36,3: 382-392 [doi: 10.2307/1387856].

Conger, Rand D. et al. 1990: Linking economic hardship to marital quality and instability. In: Journal of Marriage and the Family 52: 643-656.

Conger, Rand D.; Rueter, M. A.; Elder Jr., Glen H. 1999: Couple resilience to economic pressure. In: Journal of Personality and Social Psychology 76,1: 54-71 [doi: 10.1037//0022-3514.76.1.54].

Esser, Hartmut 2001: Integration und ethnische Schichtung. Arbeitspapiere des Mannheimer Zentrums für Europäische Sozialforschung 40. Mannheim.

Fuchs-Schündeln, Nicola; Schündeln, Matthias 2009: Who stays, who goes, who returns? East-West migration within Germany since reunification. In: Economics of Transition 17: 703-738 [doi: 10.1111/j.1468-0351.2009.00373.x].

Göbel, Jan; Habich, Roland; Krause, Peter 2010: Ost-West-Angleichung von Einkommen und Zufriedenheit im Lebenszyklus. In: Krause, Peter; Ostner, I/ona (Eds.): Leben in Ost- und Westdeutschland. Eine sozialwissenschaftliche Bilanz der deutschen Einheit 1990-2010. Frankfurt/M./New York: Campus.

Göbel, Jan et al. 2008: Daten- und Datenbankstruktur der Längsschnittstudie Sozio-oekonomisches Panel (SOEP). In: SOEP Papers 89: 1-42.

Gordon, Milton M. 1964: Assimilation in American life: The role of race, religion, and national origins. Oxford: Oxford University Press.

Griffin, Dale; Murray, Sandra; Gonzalez, Richard 1999: Difference score correlations in relationship research: A conceptual primer. In: Personal Relationships 6: 505-518 [doi: 10.1111/j.1475-6811.1999.tb00206.x].

Hank, Karsten; Kreyenfeld, Michaela; Spieß, Katharina 2004: Kinderbetreuung und Fertilität in Deutschland. In: Zeitschrift für Soziologie 33,3: 228-244.

Kalmijn, Matthijs 2005: Attitude alignment in marriage and cohabitation: the case of sex-role attitudes. In: Personal Relationships 12,4: 521-535 [doi: 10.1111/j.1475-6811. 2005.00129.x].

Klein, Thomas; Wunder, Edgar 1996: Regionale Disparitäten und Konfessionswechsel als Ursache konfessioneller Homogamie. In: Kölner Zeitschrift für Soziologie und Sozialpsychologie 48: 96-125.

Kopp, Johannes; Lois, Daniel; Kunz, Christina; Arránz Becker, Oliver 2010: Verliebt, verlobt, verheiratet. Institutionalisierungsprozesse in Partnerschaften. Wiesbaden: VSVerlag.

Kulu, Hill; Milewski, Nadja 2007: Family change and migration in the life course: An introduction. In: Demographic Research 17: 567-590 [doi: 10.4054/DemRes.2007.17.19]

Lankuttis, Teresa; Blossfeld, Hans-Peter 2003: Determinanten der Wiederheirat nach der ersten Scheidung in der Bundesrepublik Deutschland. In: Zeitschrift für Familienforschung 15,1: 5-25.

Lewis, Robert A.; Spanier, Graham B. 1979: Theorizing about the quality and stability of marriage. In: Burr, Wesley (Ed.): Contemporary theories about the family (Vol. 1). New York/London: Free Press: 268-294. 
Lois, Danie/ 2008: Arbeitsteilung, Berufsorientierung und Partnerschaftsstabilität. Ehen und nichteheliche Lebensgemeinschaften im Vergleich. In: Kölner Zeitschrift für Soziologie und Sozialpsychologie 60: 53-77 [doi: 10.1007/s11577-008-0003-z].

Lois, Danie/ 2011: Church membership and church attendance across time - A trend analysis considering differences between East and West Germany. In: Comparative Population Studies - Zeitschrift für Bevölkerungswissenschaft 36,1: 161-192 [doi: 10.4232/10.CPoS-2011-04en].

Lois, Danie/ 2013: Wenn das Leben religiös macht. Altersabhängige Veränderungen der kirchlichen Religiosität im Lebensverlauf. Wiesbaden: Springer VS.

Milewski, Nadja 2009: Fertility of immigrants: A two-generational approach in Germany. In: Demographic Research Monographs 6. Berlin/Heildelberg: Springer.

Mood, Carina 2010: Logistic Regression: Why we cannot do what we think we can do, and what we can do about it. In: European Sociological Review 26: 67-82 [doi: 10.1093/ esr/jcp006].

Peuckert, Rüdiger 2008: Familienformen im sozialen Wandel. Wiesbaden: VS-Verlag.

Pickel, Gert 2003: Areligiosität, Antireligiosität, Religiosität - Ostdeutschland als Sonderfall niedriger Religiosität im osteuropäischen Rahmen? In: Woh/rab-Sahr, Monika; Po/lack, Detlef (Eds.): Atheismus und religiöse Differenz. Opladen: Leske + Budrich: 247270.

Pötzsch, Olga 2012: Geburtenfolge und Geburtenabstand - neue Daten und Befunde. In: Wirtschaft und Statistik 2: 89-101.

Qian, Zhenchao; Lichter, Daniel T. 2007: Social boundaries and marital assimilation: Interpreting trends in racial and ethnic intermarriage. In: American Sociological Review 72: 68-94 [doi: 10.1177/000312240707200104].

Rösler, Wiebke 2010: Die ost-westdeutsche Partnerwahl. Wanderungen, Vorurteile, Wohlfahrtsunterschiede. In: Krause, Peter; Ostner, Ilona (Eds.): Leben in Ost und Westdeutschland. Eine sozialwissenschaftliche Bilanz der deutschen Einheit 19902010. Frankfurt/M./New York: Campus: 211-226.

Schmollack, Simone 2005: Deutsch-deutsche Beziehungen. Geschichten von der Liebe zwischen Ost und West. Berlin: Schwarzkopf \& Schwarzkopf.

Schneider, Norbert F.; Naderi, Robert; Ruppenthal, Silvia 2012: Familie in Deutschland nach dem gesellschaftlichen Umbruch. Sind Ost-West-Differenzierungen in der Familienforschung zwanzig Jahre nach der Wiedervereinigung noch sinnvoll? In: Huinink, Johannes; Kreyenfeld, Michaela; Trappe, Heike (Eds.): Familie und Partnerschaft in West- und Ostdeutschland. Ähnlich und doch immer noch anders. Sonderheft 9 der Zeitschrift für Familienforschung. Berlin/Toronto: Barbara Budrich: 29-54.

Schneider, Norbert F.; Tölke, Angelika; Nauck, Bernhard 1995: Familie im gesellschaftlichen Umbruch - nachholende oder divergierende Modernisierung? In: Nauck, Bernhard; Schneider, Norbert; Tölke, Angelika (Eds.): Familie und Lebensverlauf im gesellschaftlichen Umbruch. Stuttgart: Enke: 1-29.

Singer, Judith D.; Willett, John B. 2003: Applied longitudinal data analysis. Modeling change and event occurrence. Oxford: University Press.

Statistisches Bundesamt 2009: Mikrozensus 2008 - Neue Daten zur Kinderlosigkeit in Deutschland. Wiesbaden: Statistisches Bundesamt.

Storch, Kersten 2003: Konfessionslosigkeit in Ostdeutschland. In: Gärtner, Christel; Pollack, Detlef; Wohlrab-Sahr, Monika (Eds.): Atheismus und religiöse Indifferenz. Opladen: Leske + Budrich: 231-245. 
Szydlik, Marc; Schupp, Jürgen 2004: Wer erbt mehr? Erbschaften, Sozialstruktur und Alterssicherung. In: Kölner Zeitschrift für Soziologie und Sozialpsychologie 56: 609629 [doi: 10.1007/s11577-004-0106-0].

Trappe, Heike 1995: Emanzipation oder Zwang? Frauen in der DDR zwischen Beruf, Familie und Sozialpolitik. Berlin: Akademie Verlag.

Vatterrott, Anja 2011: The fertility behaviour of East to West German migrants. In: MPIDR Working Paper 2011-13.

Wagner, Gert G.; Frick, J. R.; Schupp, Jürgen 2007: The German Socio-Economic Panel Study (SOEP) - Scope, Evolution and Enhancements. In: Schmollers Jahrbuch 127: 161-191.

Wagner, Michael; Weiß, Bernd 2003: Bilanz der deutschen Scheidungsforschung: Versuch einer Meta-Analyse. In: Zeitschrift für Soziologie 32: 29-49.

Windzio, Mark 2007: Regionale Arbeitslosigkeit und Distanz zur Grenze: Individualund Kontexteffekte auf die Abwanderung von Arbeitskräften von Ost- nach Westdeutschland. In: Schmollers Jahrbuch 127: 553-583.

Zapf, Wolfgang; Mau, Steffen 1993: Eine demographische Revolution in Ostdeutschland? Dramatischer Rückgang von Geburten, Eheschließungen und Scheidungen. In: Informationsdienst Soziale Indikatoren 10: 1-5.

Translated from the original text by the Federal Institute for Population Research, for information only. The reviewed and author's authorised original article in German is available under the title "Ost-West-Paare: Verbreitung, Eigenschaften und Stabilität", DOI 10.12765/CPoS-2014-17de or URN urn:nbn:de:bib-cpos-2014-17de7, at http://www.comparativepopulationstudies.de.

Date of submission: 28.10 .2013

Date of acceptance: 06.03.2014

Prof. Dr. Daniel Lois ( $\varangle$ ). Universität der Bundeswehr München, Fakultät für Humanwissenschaften, Department of Education. München, Germany.

E-Mail: daniel.lois@unibw.de

URL: http://www.unibw.de/hum/dfb/SWM/pers/daniellois 


\section{Appendix}

Tab. A1: Descriptive statistics for the variables included into the model

\begin{tabular}{|c|c|c|c|c|c|}
\hline & $\begin{array}{c}\text { Mean } \\
\text { value / \% }\end{array}$ & SD & Min & Max & $\%$ imputed \\
\hline \multicolumn{6}{|l|}{ Couple types } \\
\hline West-west couple, western Germany & $72.1 \%$ & & 0 & 1 & \multirow{4}{*}{15.2} \\
\hline East-east couple, eastern Germany & $25.7 \%$ & & 0 & 1 & \\
\hline East-west couple, western Germany & $1.9 \%$ & & 0 & 1 & \\
\hline East-west couple, eastern Germany & $0.4 \%$ & & 0 & 1 & \\
\hline \multicolumn{6}{|l|}{ Familial living arrangements } \\
\hline $\begin{array}{l}\text { Cohabiting couples not previously } \\
\text { divorced }\end{array}$ & $7.6 \%$ & & 0 & 1 & \multirow{4}{*}{18.8} \\
\hline $\begin{array}{l}\text { Cohabiting couples previously } \\
\text { divorced }\end{array}$ & $5.3 \%$ & & 0 & 1 & \\
\hline Married not previously divorced & $75.4 \%$ & & 0 & 1 & \\
\hline Married previously divorced & $11.8 \%$ & & 0 & 1 & \\
\hline Partners have at least one child & $82.0 \%$ & & 0 & 1 & 9.0 \\
\hline $\begin{array}{l}\text { Number of children } 0-1 \text { years old in } \\
\text { the household }\end{array}$ & 0.04 & 0.2 & 0 & 3 & \multirow{4}{*}{0.0} \\
\hline Number of children 2-4 years old in & & & & & \\
\hline the household & 0.1 & 0.3 & 0 & 3 & \\
\hline Number of children over 4 years old & 0.2 & 0.5 & 0 & 4 & \\
\hline \multicolumn{6}{|l|}{ Economic situation and division of labour } \\
\hline Index of the economic situation ${ }^{\#}$ & 0.0 & 1.0 & -3.3 & 11.2 & \multirow{5}{*}{12.6} \\
\hline One partner unemployed & $20.4 \%$ & & 0 & 1 & \\
\hline Both partners unemployed & $6.6 \%$ & & 0 & 1 & \\
\hline Employment index $\#$ & 6.4 & 4.1 & 0 & 12 & \\
\hline Employment index (man-woman) & 3.2 & 5.8 & -12 & 12 & \\
\hline Hours of housework weekends ${ }^{\#}$ & 1.8 & 0.9 & 0 & 10 & \multirow{2}{*}{19.7} \\
\hline Housework (man-woman) & -1.9 & 1.8 & -10 & 10 & \\
\hline \multicolumn{6}{|l|}{ Religiousness } \\
\hline Church attendance ${ }^{\#}$ & 9.2 & 13.6 & 0 & 52 & \multirow{2}{*}{18.8} \\
\hline Church attendance (|man-woman|) & 5.0 & 10.1 & 0 & 52 & \\
\hline Both partners non-denominational & $20.2 \%$ & & 0 & 1 & \multirow{3}{*}{31.4} \\
\hline Confessional heterogamy & $26.8 \%$ & & 0 & 1 & \\
\hline Confessional homogamy & $53.1 \%$ & & 0 & 1 & \\
\hline \multicolumn{6}{|l|}{ Time indicators } \\
\hline $\mathrm{Age}^{\#}$ & 47.5 & 14.4 & 17 & 95 & 1.0 \\
\hline $\begin{array}{l}\text { Marriage duration (coded with } 0 \text { for } \\
\text { cohabiting couples, }+1 \text { ) }\end{array}$ & 20.4 & 15.6 & 1 & 72 & 22.0 \\
\hline Period 1991-1995 & $19.4 \%$ & & 0 & 1 & \multirow{5}{*}{0.0} \\
\hline Period 1996-2000 & $23.2 \%$ & & 0 & 1 & \\
\hline Period 2001-2005 & $33.6 \%$ & & 0 & 1 & \\
\hline Period 2006-2009 & $23.8 \%$ & & 0 & 1 & \\
\hline Cohort from 1971 (ref.: until 1970) & $14.3 \%$ & & 0 & 1 & \\
\hline Place of residence Berlin & $3.5 \%$ & & 0 & 1 & \multirow[t]{3}{*}{7.1} \\
\hline n (couples) & & & 16,372 & & \\
\hline n (observations) & & & 122,049 & & \\
\hline
\end{tabular}

Mean values and percentages refer to the 122,049 observations in the long format

\# = Operationalised as average value per couple, SD = Standard deviation

Source: SOEP (1990-2009, own calculations) 


\section{Comparative Population Studies}

WWW.comparativepopulationstudies.de

ISSN: 1869-8980 (Print) - 1869-8999 (Internet)

Published by / Herausgegeben von

Prof. Dr. Norbert F. Schneider

Federal Institute for Population Research

D-65180 Wiesbaden / Germany

\section{Managing Editor /}

Verantwortlicher Redakteur

Frank Swiaczny

\section{Assistant Managing Editor /}

\section{Stellvertretende Redakteurin}

Katrin Schiefer

\section{Copy Editor (German) /}

Lektorat (deutsch)

Dr. Evelyn Grünheid

\section{Layout / Satz}

Beatriz Feiler-Fuchs

E-mail:cpos@bib.bund.de

\section{Scientific Advisory Board /}

Wissenschaftlicher Beirat

Paul Gans (Mannheim)

Johannes Huinink (Bremen)

Michaela Kreyenfeld (Rostock)

Marc Luy (Wien)

Clara H. Mulder (Groningen)

Notburga Ott (Bochum)

Peter Preisendörfer (Mainz)

Zsolt Spéder (Budapest)
Board of Reviewers / Gutachterbeirat Martin Abraham (Erlangen)

Laura Bernardi (Lausanne)

Hansjörg Bucher (Bonn)

Claudia Diehl (Konstanz)

Andreas Diekmann (Zürich)

Gabriele Doblhammer-Reiter (Rostock)

Jürgen Dorbritz (Wiesbaden)

Anette Eva Fasang (Berlin)

E.-Jürgen Flöthmann (Bielefeld)

Alexia Fürnkranz-Prskawetz (Wien)

Beat Fux (Salzburg)

Joshua Goldstein (Berkeley)

Karsten Hank (Köln)

Sonja Haug (Regensburg)

Hill Kulu (Liverpool)

Aart C. Liefbroer (Den Haag)

Kurt Lüscher (Konstanz)

Emma Lundholm (Umeå)

Nadja Milewski (Rostock)

Dimiter Philipov (Wien)

Roland Rau (Rostock)

Tomáš Sobotka (Wien)

Jeroen Spijker (Barcelona)

Olivier Thévenon (Paris)

Helga de Valk (Brussel)

Heike Trappe (Rostock)

Michael Wagner (Köln) 